\title{
IMPACT OF THE MARKET CONCENTRATION ON TRADING CHAINS' PERFORMANCE IN SERBIA
}

\author{
Vera Mirović* \\ Faculty of Economics in Subotica \\ University of Novi Sad, Republic of Serbia \\ Jelena Andrašić \\ Faculty of Economics in Subotica \\ University of Novi Sad, Republic of Serbia \\ Branimir Kalaš \\ Faculty of Economics in Subotica \\ University of Novi Sad, Republic of Serbia
}

\begin{abstract}
The aim of the paper is testing the difference between the market share of three leading acquired chains and the three leading domestic trading chains in Serbia, as well as the analysis of performance between these two groups of trading chains in the period 2011-2015. Performance of trading chains is measured by profitability, liquidity and leverage indicators. Results of t-test indicate that there is a significant difference between the market share of analyzed trading chains. The analysis of the difference between observed trading chains has shown that there is a significant difference only in the trend of profitability. The correlation analysis between market share and profitability, shows that acquired trading chains with higher market share have lower profitability.
\end{abstract}

Key words: trading chains, takeover, market share, liquidity, profitability, leverage

JEL classification: G34, F15

\section{UTICAJ TRŽIŠNE KONCENTRACIJE NA PERFORMANSE TRGOVINSKIH LANACA U SRBIJI}

Sažetak: Cilj rada je da se ispita razlika između tržišnih učešća tri vodeća preuzeta trgovinska lanca $i$ tri vodeća domaća lanca u Srbiji, kao i analiza performansi između dve grupe trgovinskih lanaca u periodu 2011-2015. Performanse trgovinskih lanaca su

\footnotetext{
*vera.mirovic@ef.uns.ac.rs
} 

SERBIA

merene putem pokazatelja profitabilnosti, likvidnosti $i$ leveridža. Rezultati T-testa pokazuju da postoji značajna razlika između tržišnih učešća analiziranih trgovinskih lanaca. Analiza razlike između posmatranih trgovinskih lanaca je pokazala da postoji značajna razlika samo u trendu profitabilnosti. Ispitivanjem korelacije između tržišnog učešća i profitabilnosti, zaključeno je da preuzeti trgovinski lanci s većim tržišnim učešćem imaju manju profitabilnost.

Ključne reči: trgovinski lanci, preuzimanje, tržišno učešće, likvidnost, profitabilnost, leveridž

\section{INTRODUCTION}

The Serbian trade sector is characterized by consolidation, i.e. intensive takeover processes, especially in the case of major trade chains. Trade in Serbia is an attractive economic field for foreign investors (Stankov, Roganović and Marjanski Lazić, 2016). The process of opening Serbia's market started in 2001 by adopting a number of laws inherent in the market economy, all with the aim to ensure macroeconomic stability, deregulation and liberalization, to enhance better relations with international financial institutions and to attract foreign investment. During this period, a large number of foreign-owned retail chains entered the Serbian market through greenfield investments and acquisitions, changing significantly the position of some domestic-owned trading chains in the branch. Foreign investors have their own interest in entering the Serbian trade market through acquisitions of domestic-owned companies. In these acquisitions they expect to achieve synergistic effects, which will contribute to revenue growth, cost reduction and market share growth. The aim of this paper is to investigate the differences between the leading acquired and leading domestic trading chains on the Serbian market, measured by market share and performance of the company's business. The main research question is whether domestic or acquired trade companies have a better performance in Serbia? The other question to answer is whether there is a correlation between the market share and the operating performance of the domestic and acquired trade chains.

The paper is structured in five parts. After the Introduction, which explains the main tendencies on the Serbian trade market in the last one and a half decades, follows the second part Literature review. The second part explains the theoretical background of the research, i.e. gives an overview of the previously undertaken similar researches regarding the methodology and the results. The third part, Data and methodology, clarifies the source of the data sample, and the variables, as well as the methodology itself and gives the overview of the defined hypothesis. The next part, Empirical analysis and results, reveals the results of t-test, MANOVA test and correlation analysis. The last part of the 
paper, Conclusion, summarizes the results of the research, explains the results of the hypothesis testing and clarifies the contribution of the paper.

\section{LITERATURE REVIEW}

Several studies in different branches had investigated the market concentration measured by the Herfindahl Hirschman Index $(H H I)$ and Concentration index $(C R n)$ based on different independent variables. Mijić, Vuković and Jakšić (2014) analyzed the concentration of the audit services market in the Republic of Serbia in the period 2008-2011. The concentration of the audit services market was measured by the Herfindahl Hirschman Index $(H H I)$ and Concentration index $(C R n)$ based on the following independent variables: operating revenue, net earnings, number of employees and number of audit clients. The results of their study indicated a moderate concentration based on operating revenue as a criterion of measurement. While observing market concentration based on other variables, it was noticed that there was no dominance of the "big four": Price Waterhouse Coopers, Deloitte, Ernst \& Young and KPMG. An equivalent research as regards methodology, was undertaken by Lončar, Đorđević, Lazić, Milošević and Rajić (2016), in the case of the market concentration of the banking sector in Serbia, Croatia, Romania and the Czech Republic. The results of this research regarding the indicators of concentration and profitability showed that a positive correlation between these variables was proven in cases in which it was not expected. Once the concentration of the market has been defined, the question is what the correlation between the market share and the firms' performances, presented by firms' profitability, liquidity and debt ratio is. The theoretical attitudes related to this question are divide. There is evidence for a positive and also for a negative relationship between the concentration ratio and firms profitability. The positive relation is justified by the fact that a higher level of concentration provides a larger amount of revenue for the firms, and in that way, they can enhance their net income. The following studies confirmed the positive relationship between market share and profitability. Goddard, Tavakoli and Wilson (2005) were investigating the main determinants of firms' profitability in the manufacturing and service industry in Belgium, France, Italy and the UK. According to this study, there is a positive relationship between market share and profitability, this relationship is stronger in the manufacturing industry than in services. The same study showed that firm's gearing ratio waws negatively correlated to its profitability, and firms with higher liquidity tended to be more profitable. Molyneux and Thornton (1992) confirmed also a positive relationship between concentration ratio and profitability on the example of the banking sector. Bennenbroek and Harris (1995), investigated the determinants of profitability 

SERBIA

for New Zealand manufacturing industry, and they found that market power and market efficiency determine the firms' profitability.

In their research regarding the profitability determinants for $45 \mathrm{UK}$ electrical companies, Grinyer and McKiernan (1991), showed a positive relationship between market share and corporate profitability. Furthermore, they concluded that among market share, determinants like capital intensity, growth of sales, working capital and decentralization had a significant impact on firms' profitability. McDonald (1999) examined the determinants of profitability of Australian manufacturing companies. His results support the positive correlation between an industry concentration and a firm' profitability. Glancey (1998), found on a sample of 38 small manufacturing firms in the Tayside Region of Scotland, that size, age, location and industry group had a limited value in explaining profitability. Andrašić, Mirović, Mijić and Kalaš (2018) examined the impact of factors on profitability of medium and large companies in agricultural sector in the region of Vojvodina in the Republic of Serbia and showed statistically significant impact of company size, current liquidity, debt, market share sales revenue growth, insurance and export on return on assets as a main profitability determinant. Looking the character of factor's influence, models reflect negative impact of company size and debt on return on assets as well as positive impact of current liquidity, market share, sales revenue growth, insurance and export on return on assets of medium and large agricultural companies in Vojvodina region in the Republic of Serbia. Blažková and Dvouletý (2017), investigated the sectoral determinants on profitability in the Czech food processing industry in the period 2003-2014. Sectoral profitability, as the dependent variable, was measured by ROA and ROE. The results showed a positive impact of higher market concentration on sectoral profitability, in both cases. In addition, they showed that an increase in productivity was related to an increase of ROA and ROE, and it was proved that high indebtedness affects the profitability negatively. In their research Siminica, Carstina, Circiumaru and Netoiu (2018) considered the correlation between the market concentration and profitability, measured by net profit, ROA, ROE and the profit margin in the chemical products industry. The results of this research showed a weak correlation between the market concentration and profitability measured by ROA and profit margin. Contrary to that, the correlation between market share and profitability, measured by net profit and ROE, was strong and positive.

On the other hand, there is a view that there is a negative correlation between market share and profitability, which is according to some authors Lončar et al. (2016) supported by most studies. A negative correlation between market concentration and profitability can be explained by the fact that higher concentration level could be related to a lower price policy, or higher levels of 
expenses, which could cause a lower profitability ratio of the related firms. The following studies confirm that negative relationship. Vuković, Mijić and Spahić (2015) investigated the market concentration of the tobacco producers in Serbia in the period from 2010 to 2013. The market concentration was measured by Herfindahl Hirschman index $(H H I)$ and Concentration index $(C R n)$ based on independent variables, as follows: operating revenue, net earnings, equity and number of employees. The result of market concentration analysis, based on the most referable variable operating revenue, has shown that the Serbian tobacco market was highly concentrated in an oligopoly. It is important to notice that, although leading companies had the highest market share, their operating results were surprisingly poor in terms of effectiveness, structure of assets and financial performance. A similar study Nuševa, Mijić and Jakšić (2017), focused on the performances of the coffee processors and the coffee market in Serbia. The focus of this research was to analyze the market concentration, profitability and the profitability determinants on the sample of 40 coffee processing companies, which were divided into two groups (large and small coffee processors). The results of this study showed that two large coffee processors had the highest market share, although small coffee processors had a significantly better profitability. In addition, the study results showed that the profitability ratio was in a positive correlation with the inventory turnover and negatively correlated to the market share. Jay Bourgeois III, Ganz, Gonce and Nedell (2014) also confirmed in their study a negative relationship between concentration ratio and profitability in several branches like food and drug, insurance, as well as in healthcare industries. Eriotis, Frangouli and Ventoura-Neokosmides (2011), also found a negative correlation between concentration ratio and profitability. Furthermore, they also investigated the relationship between debt ratio and profitability, and came to the same conclusion as we expected in our study that financing investments using retained profits were more profitable than using borrowed funds. Špička (2016) was comparing the market concentration of grocery retailers in the six countries of Central Europe. The concentration was measured by CR4 ratio, Herfindahl Hirschman Index and the GRS index and the results of this study showed that the grocery retail market is characterized by an asymmetric oligopoly. The results of the research also showed that there was no strong relationship between the market concentration and the profitability of the grocery retailers. Keil (2017) explains the perennial paradox: a significant negative econometric relationship between profitability and market share concentration. He states that the reason for this phenomenon lies in the cost competitiveness of the competitors. Namely, the profitability of a firm is endangered if the product price correlates positively with average industry costs. Sunk costs can make an industry exit expensive and not possible for firms. This study proves that concentration can lead to lower levels of profitability. 


\section{DATA AND METHODOLOGY}

The aim of this study is to test the difference between market share of the three leading acquired trading chains (Group 1) and the three leading domestic trading chains (Group 2) in Serbia, as well as the analysis of performance between these two groups of retail chains in the period 2011-2015. The criterion for selection of retail chains is the size of operating income. Performance of retail chains is presented by profitability, liquidity and leverage indicator. Financial statements data were downloaded from the website of the Business Registers Agency. The research included statistical methods such as t-test, MANOVA test and correlation analysis. The following hypotheses were tested:

H1: There is a significant difference in market share level between acquired trading chains and domestic trading chains.

$\mathrm{H} 2$ : There is a significant difference in performance level between acquired trading chains and domestic trading chains.

H2a: There is a significant difference in profitability level between acquired trading chains and domestic trading chains.

$\mathrm{H} 2 \mathrm{~b}$ : There is a significant difference in liquidity level between acquired trading chains and domestic trading chains.

$\mathrm{H} 2 \mathrm{c}$ : There is a significant difference in leverage level between acquired trading chains and domestic trading chains.

Table 1

Variable description

\begin{tabular}{ccc}
\hline Analyzed factors & Symbol & Calculation \\
\hline Market share & MSH & Operating income/Total income \\
Profitability & ROA & Net profit/Total assets \\
Liquidity & LIQ & Working capital/Short-term liabilities \\
Leverage & LEV & Total liabilities/Total assets \\
\hline
\end{tabular}

Note. Calculated by the authors.

Market concentration manifests an essential measure for competition between companies in an industry. A higher level of concentration means a greater amount of revenue, as a positive part of net income (Nuševa, Mijić and Jakšić, 2017). Profitability is one of the most important indicators of business success and it indicates the earning power and business success of a company (Kimmel, Weygandt and Kieso, 2012). Most often used ratios for testing company's profitability are ROA (return on assets ratio) and ROE (return on equity ratio). According to Jakšić, Mijić, Zekić and Poljašević (2015), ROA ratio should be higher than 0.1 and ROE ratio should be higher than 0.15 . Liquidity is the ability of a company to pay off its immediate liabilities where the ratio of current liquidity should be greater than one. Leverage measures the share of 
borrowed funds in total company assets, i.e. share of long-term debt in total capital and this ratio should be as low as possible (Damodaran, 2006)

\section{EMPIRICAL ANALYSIS AND RESULTS}

Before we determine potential difference between leading acquired trading chains and leading domestic trading chains in terms of market share and performances, it is necessary to show current state and trend of these variables. First, the trend of market share of trading chains in Serbia is presented, as well as main performances such as profitability, liquidity and leverage.

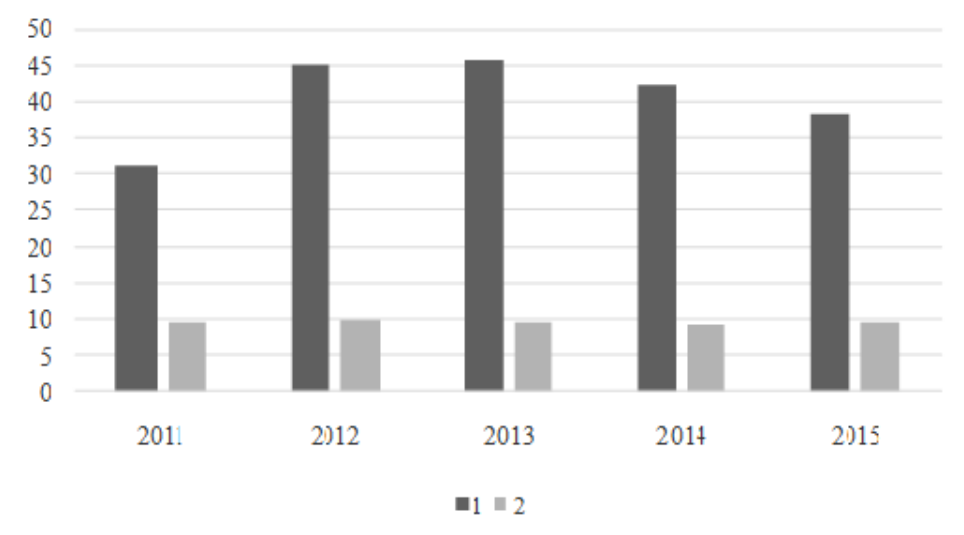

Figure 1. Market share of trading chains in Serbia for the period 2011-2015 (Group 1 three leading acquired trading chains; Group 2 - three leading domestic trading chains). Note. Calculated by the authors.

The figure shows market share of three leading acquired trading chains and three leading domestic trading chains from 2011 to 2015. As it can be seen, acquired trading chains had five times more market share than domestic trading chains. Increase in market share is most often the result of economies of scale (Andrašić, Milenković, Mijić, Mirović, \& Kalaš, 2018). Acquired trading chains had an average market share of $40.48 \%$ in observed period while domestic trading chains had only $9.16 \%$ on the Serbian market.

Although acquired trading chains had higher market share compared to domestic trading chains in Serbia, their average profitability was negative. Namely, the average return on assets of acquired trading chains was $-11,81 \%$ which was far less than profitability of domestic trading chains, and analyzed chains had a similar trend of liquidity and leverage movement in five year period. 
8 | IMPACT OF THE MARKET CONCENTRATION ON TRADING CHAINS' PERFORMANCE IN SERBIA
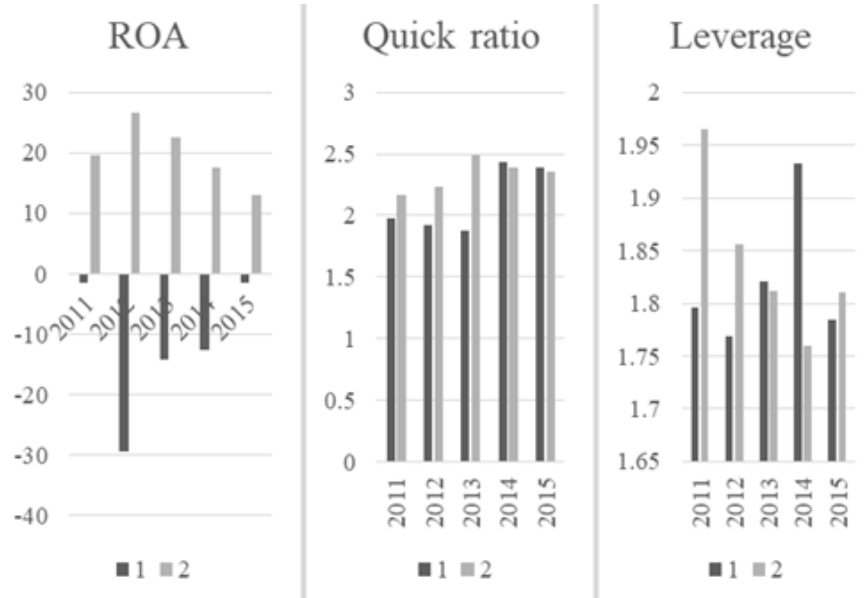

Figure 2. Performances of trading chains in Serbia for the period 2011-2015 (Group 1 three leading acquired trading chains; Group 2 - three leading domestic trading chains) Note. Calculated by the authors

In order to determine if there is a significant difference in market share between three leading acquired trading chains and three leading domestic trading chains, analysis has included t-test, MANOVA tests as well as correlation analysis.

Table 2

\section{Independent Sample Test}

\begin{tabular}{|c|c|c|c|c|c|c|c|}
\hline \multirow{2}{*}{ MSH } & \multicolumn{2}{|c|}{$\begin{array}{c}\text { Levene's Test for } \\
\text { Equality of } \\
\text { Variances } \\
\end{array}$} & \multicolumn{5}{|c|}{ t-test for Equality of Means } \\
\hline & $\mathrm{F}$ & Sig. & $\mathrm{t}$ & df & $\begin{array}{c}\text { Sig. } \\
\text { (2tailed) }\end{array}$ & $\begin{array}{c}\text { Mean } \\
\text { Difference }\end{array}$ & $\begin{array}{l}\text { Std. Error } \\
\text { Difference }\end{array}$ \\
\hline $\begin{array}{l}\text { Equal } \\
\text { variances } \\
\text { assumed }\end{array}$ & 10.591 & .003 & 6.936 & 28 & .000 & 4.19561 & 60489 \\
\hline $\begin{array}{l}\text { Equal } \\
\text { variances } \\
\text { not assumed }\end{array}$ & & & 6.936 & 16.18 & .000 & 4.19561 & 60489 \\
\hline \multicolumn{4}{|c|}{ 95\% Confidence Interval of the Difference } & \multicolumn{2}{|c|}{$\begin{array}{l}2.9565 \\
2.9145\end{array}$} & \multicolumn{2}{|c|}{$\begin{array}{l}5.4346 \\
5.4767\end{array}$} \\
\hline
\end{tabular}

Note. Calculated by the authors.

Based on the value of Levene's test it can be conclude there is a statistically significant difference in market share between leading acquired trading chains and domestic trading chains. Next, multivariate analysis of variance is presented 
to demonstrate if there is a significant difference in the performance level of observed trading chains.

Table 3

Descriptive statistics

\begin{tabular}{ccccc}
\hline Variables & Group & Mean & Std. Deviation & N \\
\hline ROA & 1 & -3.9382 & 7.39363 & 15 \\
& 2 & 6.6284 & 2.88707 & 15 \\
LIQ & Total & 1.3451 & 7.69999 & 30 \\
& 1 & .7064 & .23505 & 15 \\
& 2 & .7745 & .08199 & 15 \\
LEV & Total & .7405 & .17640 & 30 \\
& 1 & .6068 & .21173 & 15 \\
& 2 & .6136 & .08146 & 15 \\
& Total & .6102 & .15766 & 30 \\
\hline
\end{tabular}

Note. Calculated by the authors.

As we can see, the leading acquired trading chains had less profitability and there was a negative mean value of $3.94 \%$ in the analyzed period. This was far less than in the case of the domestic trading chains which recorded an average value of $6,63 \%$.

Table 4

Multivariate test

\begin{tabular}{clccccc}
\hline Effect & \multicolumn{1}{c}{ Test } & Value & \multicolumn{1}{c}{$\mathbf{F}$} & $\begin{array}{c}\text { Hypothesis } \\
\text { df }\end{array}$ & Error df & Sig. \\
\hline Intercept & Pillai's Trace & .987 & $642.062^{\mathrm{b}}$ & 3.000 & 26.000 & .000 \\
& Wilks' & .013 & $642.062^{\mathrm{b}}$ & 3.000 & 26.000 & .000 \\
& Lambda & & & & & \\
& Hotelling's & 74.084 & $642.062^{\mathrm{b}}$ & 3.000 & 26.000 & .000 \\
& $\begin{array}{l}\text { Trace } \\
\text { Roy's Largest }\end{array}$ & 74.084 & $642.062^{\mathrm{b}}$ & 3.000 & 26.000 & .000 \\
& Root & & & & & \\
\hline Group & Pillai's Trace & .543 & $10.318^{\mathrm{b}}$ & 3.000 & 26.000 & .000 \\
& Wilks' & .457 & $10.318^{\mathrm{b}}$ & 3.000 & 26.000 & .000 \\
& Lambda & & & & & \\
& Hotelling's & 1.191 & $10.318^{\mathrm{b}}$ & 3.000 & 26.000 & .000 \\
& $\begin{array}{l}\text { Trace } \\
\text { Roy's Largest }\end{array}$ & 1.191 & $10.318^{\mathrm{b}}$ & 3.000 & 26.000 & .000 \\
& Root & & & & & \\
\hline
\end{tabular}

Note. Calculated by the authors.

a. Design: Intercept + group

b. Exact statistic 
10 IMPACT OF THE MARKET CONCENTRATION ON TRADING CHAINS' PERFORMANCE IN SERBIA

Furthermore, the standard deviation is higher in Group 1 than Group 2 which implies that there were greater oscillations between minimum and maximum value of this indicator. With regard to liquidity and leverage, there was a similar trend of movement and no major differences between selected indicators can be observed.

Table 4 includes four Multivariate test to determine if there is a significant difference in the performance level of the analyzed trading chains. Results of Pillai's Trace test show that values are less than 0.05 which implies that there is a significant difference in performance level from 2011 to 2015.

Table 5

Tests of Between-Subject Effects

\begin{tabular}{|c|c|c|c|c|c|c|}
\hline Source & $\begin{array}{l}\text { Dependen } \\
\text { t Variable }\end{array}$ & $\begin{array}{c}\text { Type III } \\
\text { Sum of } \\
\text { Squares }\end{array}$ & df & $\begin{array}{c}\text { Mean } \\
\text { Square }\end{array}$ & $\mathbf{F}$ & Sig. \\
\hline \multirow{3}{*}{$\begin{array}{l}\text { Corrected } \\
\text { Model }\end{array}$} & $\mathrm{ROA}$ & $837.935^{\mathrm{a}}$ & 1 & 837.395 & 26.584 & .000 \\
\hline & LIQ & $.035^{\mathrm{b}}$ & 1 & 0.035 & 1.123 & .298 \\
\hline & LEV & $.000^{\mathrm{c}}$ & 1 & .000 & .013 & .908 \\
\hline \multirow[t]{3}{*}{ Intercept } & ROA & 54.276 & 1 & 54.276 & 1.723 & .200 \\
\hline & LIQ & 16.450 & 1 & 16.450 & 530.904 & .000 \\
\hline & LEV & 11.172 & 1 & 11.172 & 434.142 & .000 \\
\hline \multirow[t]{3}{*}{ Group } & ROA & 837.395 & 1 & 837.395 & 26.584 & .000 \\
\hline & LIQ & .035 & 1 & .035 & 1.123 & .298 \\
\hline & LEV & .000 & 1 & .000 & .013 & .908 \\
\hline \multirow[t]{3}{*}{ Error } & ROA & 882.013 & 28 & 31.500 & & \\
\hline & LIQ & .868 & 28 & 0.031 & & \\
\hline & LEV & .721 & 28 & 0.026 & & \\
\hline \multirow[t]{3}{*}{ Total } & ROA & 1773.683 & 30 & & & \\
\hline & LIQ & 17.352 & 30 & & & \\
\hline & LEV & 11.892 & 30 & & & \\
\hline \multirow{3}{*}{$\begin{array}{l}\text { Corrected } \\
\text { Total }\end{array}$} & ROA & 1719.407 & 29 & & & \\
\hline & LIQ & .902 & 29 & & & \\
\hline & LEV & .721 & 29 & & & \\
\hline
\end{tabular}

Note. Calculated by the authors.

a. R Squared $=.487$ (Adjusted R Squared $=.469)$

b. $\mathrm{R}$ Squared $=.039$ (Adjusted R Squared $=.004)$

c. R Squared $=.000$ (Adjusted R Squared $=-.035$ )

After Multivariate tests had identified that there was a significant difference in the performance between leading acquired trading chains and domestic trading chains, Table 5 analyzed performance in terms of profitability, liquidity and leverage. Based on values from Group, results showed there was a significant 
difference in the profitability level of trading chains. On the other hand, there was no significant difference in the liquidity and leverage level of observed trading chains.

Table 6

\section{Correlation}

\begin{tabular}{llcc}
\hline Variables & & ROA & MSH \\
\hline ROA & Pearson Correlation & 1 & $-.495^{* *}$ \\
& Sig. (2-tailed) & & .005 \\
& $\mathrm{~N}$ & 30 & 30 \\
\multirow{3}{*}{ MSH } & Pearson Correlation & $-.495^{* *}$ & 1 \\
& Sig. (2-tailed) & .005 & \\
& $\mathrm{~N}$ & 30 & 30 \\
\hline
\end{tabular}

Note. Calculated by the authors.

** Correlation is significant at the 0.01 level (2-tailed).

Table 6 shows a potential correlation between market share and profitability of trading chains and the results confirmed that there was a negative and significant correlation between selected variables. It means that higher market share leads to less profitability. In addition, the value of Pearson test reflects a presence middle level of correlation.

\section{CONCLUSION}

The characteristics of trading sector in Serbia are characterized by market consolidation followed by intensive acquisition processes of trading chains. With the entry of foreign investors and large trading chains into the Serbian market, economic structure and position of domestic trading chains are significantly changed. Company success can be measured in different ways, but the profitability is certainly one of the most important indicators. On the other hand, in line with competitive business conditions, companies struggle for their position on the market. As the relevant literature review shows, a large number of studies examined the profitability trend and market share of companies. This study analyzed the difference in market share between leading acquired trading chains and leading domestic trading chains in Serbia for the period 2011-2015. Empirical analysis included T-test, multivariate analysis of variance and correlation analysis in order to determine the potential statistical significant difference in terms of market share, profitability, liquidity and leverage. Results of the t-test show that there is a significant difference in market share between analyzed trading chains and it means that hypothesis $\mathrm{H} 1$ can be fully accepted. 

SERBIA

Hypothesis $\mathrm{H} 2$ cannot be fully accepted because there is only a significant difference in profitability level between observed trading chains. Namely, the study has shown the absence of significant difference in terms of liquidity and leverage between trading chains. This means that hypothesis $\mathrm{H} 2 \mathrm{a}$ can be fully accepted whereas hypothesis $\mathrm{H} 2 \mathrm{~b}$ and $\mathrm{H} 2 \mathrm{c}$ need to be rejected. Furthermore, the research has identified a negative and significant correlation between market share and profitability, which means that trading chains with higher market share had lower level of profitability in the observed period. |This study is a contribution to the analysis of the Serbian market with regard to market share and business performance of domestic and acquired retail chains.

\section{REFERENCE}

Andrašić, J., Mijić, K., Mirović, V., \& Kalaš, B. (2018). The modelling factors of agricultural companies performances. Custos e @ gronegocio on line, 14(4), 223-240.

Andrašić, J., Milenković, N., Mijić, K., Mirović, V., \& Kalaš, B. (2018). The impact of acquisitions on profitability: Evidence from the banking sector in Serbia. Economic Studies Journal, 27(4), 83-99.

Bennenbroek, N., \& Harris, R. I. D. (1995). An investigation of the determinants of profitability in New Zealand manufacturing industries in 1986-87. Applied Economics, 27(11), 1093-1101.

Blažková, I., \& Dvouletý, O. (2017). Drivers of ROE and ROA in the Czech Food Processing Industry in the Context of Market Concentration. AGRIS on-line Papers in Economics and Informatics, 9(3), 3-14.

Damodaran, A. (2006). Damodaran on Valuation: Security Analysis for Investment and Corporate Finance (2nd Edition). New Jersey, USA: John Wiley\&Sons.

Eriotis, N. P., Frangouli, Z., \& Ventoura-Neokosmides, Z. (2011). Profit Margin And Capital Structure: An Empirical Relationship. Journal of Applied Business Research (JABR), 18(2), 85-88.

Glancey, K. (1998). Determinants of growth and profitability in small entrepreneurial firms. International Journal of Entrepreneurial Behavior \& Research, 4(1), 18-27.

Goddard, J., Tavakoli, M., \& Wilson, J. O. S. (2005). Determinants of profitability in European manufacturing and services: evidence from a dynamic panel model. Applied Financial Economics, 15(8), 1269-1282. 
Grinyer, P. H., \& McKiernan, P. (1991). The Determinants of Corporate Profitability in the UK Electrical Engineering Industry. British Journal of Management, 2(1), 17-32.

Jakšić, D., Mijić, K., Zekić, S., \& Poljašević, J. (2015). Comparative profitability analysis of milk production companies to milk processing companies. Custose @gronegócio, 11(3),206-226.

Jay Bourgeois III, L., Ganz, A., Gonce, A., \& Nedell, K. (2014). Profitability of industries and firms over time. Journal of Strategy and Management, 7(3), 210-225.

Keil, J. (2017). Explaining the Concentration-Profitability Paradox. Review of Political Economy, 29(2), 209-231.

Kimmel, P., Weygandt, J., \& Kieso, D. (2012). Accounting. New Jersey, USA: John Wiley.

Lončar, D., Đorđević, A., Lazić, M., Milošević, S., \& Rajić, V. (2016). Interplay between market concentration and competitive dynamics in the banking sector: Evidence from Serbia, Croatia, Romania and the Czech Republic. Ekonomika preduzeća, 64(5-6), 332-346.

McDonald, J. T. (1999). The Determinants of Firm Profitability in Australian Manufacturing. The Economic Record, 75(2), 115-126.

Mijić, K., Vuković, B., \& Jakšić, D. (2014). Koncentracija tržišta revizijskih usluga u Republici Srbiji. Ekonomske teme, 52(1), 117-130.

Molyneux, P., \& Thornton, J. (1992). Determinants of European bank profitability: A note. Journal of banking \& Finance, 16(6), 1173-1178.

Nuševa, D., Mijić, K., \& Jakšić, D. (2017). The performances of coffee processors and coffee market in the Republic of Serbia. Economics of Agriculture, 64(1), 307-322.

Siminica, M., Carstina, S. V., Circiumaru, D., \& Netoiu, L. (2018). The impact of market concentration ration on the productivity Romanian chemical industry. Revista de Chimie, 69(3), 697-702.

Stankov, B., Roganović, M., \& Marjanski Lazić, S. (2016). Attractiveness of Serbian retail industry for foreign investors with reference to the company Delhaize group. Škola biznisa, 2/2016, 47-68.

Špička, J. (2016). Market Concentration and Profitability of the Grocery Retailers in Central Europe. Central European Business Review, 5(3), 524. 
14 I IMPACT OF THE MARKET CONCENTRATION ON TRADING CHAINS' PERFORMANCE IN SERBIA

Vuković, B., Mijić, K., \& Spahić, N. (2015). Concentration of tobacco market: evidence from Serbia. Economics of Agriculture, 62(2), 385-398.

Delivered: 27.09.2019. Accepted: 05.12.2019. 